\title{
What constitutes evidence of poor prison conditions after Aranyosi and Căldăraru? Examining the role of inspection and monitoring bodies in European Arrest Warrant decision-making
}

\begin{abstract}
The case of Aranyosi and Căldăraru confirms that where prison conditions are so poor as to breach fundamental rights, the nonexecution of a European Arrest Warrant is justified. Given the high stakes nature of such a decision, this article examines a critical question: what will be the possible sources of evidence which can and should be used in such an assessment? The article posits that prison inspection and monitoring bodies, which have the task of visiting prisons and reporting on them, with a view to the prevention of ill-treatment, will take on an important role in this decision-making process. The article examines what this role might entail, and the implications of the decision for prison inspection and monitoring bodies.
\end{abstract}

\section{Introduction}

The decision of the Court of Justice of the European Union (hereafter "ECJ") in Aranyosi and Căldăraru" has attracted attention for the way in which the Court balanced fundamental rights against the principles of mutual trust and recognition within the Area of Freedom, Security and Justice (hereafter "AFSJ"). The Court's decision that an executing judicial authority must postpone its decision on the surrender of a person who is the subject of a European Arrest Warrant (hereafter "EAW") until it is satisfied that there is no real risk of inhuman

\footnotetext{
1 Joined Cases C-404/15 \& C-659/15 PPU Pál Aranyosi and Robert Căldăraru v Generalstaatanwaltschaft Bremen, ECLI:EU:C:2016:198.
} 
or degrading treatment arising from the detention conditions in the requesting state, has brought the issue of poor prison conditions as a threat to judicial cooperation into sharp relief. The ECJ has required national judicial authorities to obtain specific and up-to-date information on the detention conditions to which a person will be subject in the requesting Member State in order to inform their decisions on the execution of EAWs in this context. Questions of the manner and provenance of such information will become crucial to the decision of a court as to whether or not there is a real risk of a violation of fundamental rights through the execution of an EAW. Some critical issues which have been raised by the decision (albeit not answered by it) concern how, from whom, and to what standard, such information is to be provided. This aspect of the decision has, thus far, been somewhat overlooked.

This article examines what types of bodies might provide this critical evidence, and the nature of the material to be provided. It argues that domestic prison inspection and monitoring bodies are likely to play an important role in providing such information, and, as such, will come under increasing scrutiny by European Union institutions. While they vary in their activity across Member States, generally, prison inspection and monitoring bodies have the objective of supporting the general prevention of torture and inhuman and degrading treatment in prisons through visiting prisons and commenting on the findings of such visits. Prison inspection and monitoring bodies exist in all Member States, and establishing such bodies is a requirement of the European Prison Rules, ${ }^{2}$ a soft law instrument created by the Council of Europe. Many prison inspection and monitoring bodies fall under the title of 'National Preventive Mechanisms'

\footnotetext{
2 "Recommendation Rec(2006)2 of the Committee of Ministers to Member States on the European Prison Rules", Council of Europe: Committee of Ministers, 11 January 2006, Rule 9.
} 
(hereafter "NPMs"), established under the United Nations Optional Protocol to the Convention against Torture (hereafter "OPCAT”), which all Member States, bar Ireland, Belgium, Slovenia, and the Czech Republic, have signed and ratified. NPMs are independent bodies tasked with visiting places where people are deprived of their liberty with purpose of reducing the likelihood of torture and ill-treatment taking place. ${ }^{3}$ This article argues that prison inspection and monitoring bodies, especially when they are independent, are, following Aranyosi and Căldăraru, likely to play a key role in the provision of evidence when questions about the compliance of prison conditions with fundamental rights must be addressed in EAW decisions.

The article begins with a brief assessment of the EU's increasing attention to prison conditions as a source of threat to mutual trust. It then examines the ECJ decision in Aranyosi and Căldăraru, and the test proffered by the ECJ for national judicial authorities to apply when deciding if prison conditions are a threat to fundamental rights such that an EAW should not be executed. The article examines what sources will be suitable as evidence in such decisions, before exploring the role inspection and monitoring bodies could play in providing information on prison conditions. It argues that prison inspection and monitoring bodies will have an important role to play in decision-making concerning prison conditions and EAWs, especially when an executing judicial authority is conducting a detailed exploration of the specific risk faced by the person subject to the EAW. The article examines the legal frameworks for, and work of, such bodies, noting that their focus on human rights compliance means they will be especially useful sources of information on prison conditions. The article concludes that,

\footnotetext{
${ }^{3}$ It is not clear when Ireland will ratify OPCAT. Ireland presently has an Inspector of Prisons, established under statute by the Prisons Act 2007.
} 
following this decision, prison inspection and monitoring bodies will take on increased importance within the AFSJ both as information-providers for executing judicial authorities in their decisions about prison conditions, and as ways to provide confidence in a Member State's prison system. It posits that Member States and institutions of the European Union will need to pay more attention to the operation, powers, and activities of prison inspection and monitoring bodies as they become central players in the maintenance of mutual trust.

\section{Prison conditions as a threat to mutual trust}

The decision in Aranyosi and Căldăraru arose out of a preliminary reference from a German court to the ECJ concerning the issue of whether or not the execution of an EAW is impermissible in circumstances where there are strong indications that the detention conditions in the issuing Member State infringe Article 6 of the Treaty of the European Union. At the heart of the decision is the question of the limits of mutual recognition in the Area of Freedom, Security and Justice. The Court has strongly insisted on mutual recognition based on mutual trust in the criminal justice area, ${ }^{4}$ and the Framework Decision establishing the EAW also applies mutual recognition to extradition processes amongst Member States. Tensions between these two concepts have long been noted in the literature, ${ }^{5}$ and Van Ballegooij and Bárd argue that the rather bald insistence on mutual recognition in this area has led to uncertainty about how fundamental rights should be taken into

\footnotetext{
${ }^{4}$ Case C-303/05, Advocaten voor de Wereld, Radu [2013] ECR 39; Van Ballegooij and Bárd, 'Mutual Recognition and Individual Rights. Did the Court Get it Right?' (2016) 7(4) New Journal of European Criminal Law 439. ${ }^{5}$ See, for example, Mitsilegas, 'The Limits of Mutual Trust on Europe's Area of Freedom, Security and Justice' (2012) 31 Yearbook of European Law 319; Mitsilegas, 'The Symbiotic Relationship Between Mutual Trust and Fundamental Rights in Europe's Area of Criminal Justice' (2015) 6(4) New Journal of European Criminal Law 457.
} 
consideration when making such decisions. ${ }^{6}$ The ECJ initially proved reluctant to interpret the FD EAW as allowing an executing judicial authority to refuse surrender on the basis of infringements to human rights. ${ }^{7}$ Nor did the European Commission take up the invitation of the European Parliament to introduce a proportionality check when issuing mutual recognition decisions. ${ }^{8}$ Some room for manoeuvre was opened up, however, by the ECJ in its Opinion 2/13 on the draft accession agreement of the EU to the European Convention on Human Rights. While the ECJ held that a Member State must presume all other Member States to comply with EU law, including fundamental rights provisions, it also noted that there could be 'exceptional circumstances' which would permit a deviation from the generally applicable principle of mutual trust. ${ }^{9}$ It was these 'exceptional circumstances' that were at issue in Aranyosi and Căldăraru.

In Aranyosi and Căldăraru the Court examined the application of these principles in circumstances where that there is a threat to fundamental rights arising out of prison conditions. The ECJ noted that the prohibition of torture and inhuman or degrading treatment or punishment is absolute, regardless of the circumstances, and that Article 3 of the European Convention on Human Rights has the same meaning as Article 4 of the Charter of Fundamental Rights. ${ }^{10}$ As such, there may be some circumstances in which execution of an EAW may not be ordered. The European Arrest Warrant system is not, as the ECJ reiterated, to have the effect of modifying the obligation to

\footnotetext{
${ }^{6}$ Van Ballegooij and Bárd, ibid.

${ }^{7}$ Radu [2013] ECR 39.

${ }^{8}$ European Parliament resolution of 27 February 2014 with recommendations to the Commission on the review of the European Arrest Warrant (2013/2109 (INL)), P7 TA-PROV(2014)0174.

${ }^{9}$ Opinion $\overline{2} / 13$ of 18 December 2014 (Opinion pursuant to Article 218(11) TFEU.

${ }^{10}$ Joined Cases C-404/15 \& C-659/15 PPU Aranyosi and Căldăraru, 9.
} 
respect fundamental rights. Therefore, when there is evidence of a real risk of inhuman or degrading treatment to those detained in the issuing Member State, the judicial authority considering the execution of the warrant "is bound" 11 to assess the existence of that risk. When that risk is made out to the satisfaction of the national judicial authority, the EAW must not be executed. ${ }^{12}$

Concern about prisons and the implications of poor prison conditions for the operation of the AFSJ has, in fact, been building for some time now within European Union institutions. While the EU has moved rather more sluggishly than the Council of Europe in the area of protection of the rights of prisoners, it has, as Baker puts it, increasingly become 'penal actor'. ${ }^{13}$ Most directly, the European Union has created Framework Decisions which provide for the mutual recognition of conditions placed on people awaiting a criminal trial, ${ }^{14}$ and which allow for prisoners to serve their sentences in another member state. ${ }^{15}$ Fundamental rights issues in prisons came to prominence in the European Parliament's resolution of 2011, which stated that prison overcrowding and allegations of poor treatment of detainees may undermine the trust which underpins judicial cooperation in criminal matters and, specifically stated that prison conditions which are below the standards expected by the Council of Europe could act as an impediment to the transfer of

\footnotetext{
${ }^{11}$ Ibid., 88.

${ }^{12}$ This raises the intriguing possibility of whether the principle aut dedere aut judiciaire would apply in such circumstances. This matter is beyond the scope of this paper, but merits much further analysis.

${ }^{13}$ Baker, "The Emerging Role of the EU as a Penal Actor" in Daems, Van Zyl Smit and Snacken (Eds), European Penology? (Hart Publishing, 2014)

${ }_{14}$ OJ L 294 20-49, "Council Framework Decision 2009/829/JHA of 23 October 2009 on the application, between Member States of the European Union, of the principle of mutual recognition to decisions on supervision measures as an alternative to provisional detention", 2009 (hereinafter the 'European Supervision Order').

15 OJ L 327 27-46, "Council Framework Decision 2008/909/JHA of 27 November 2008 on the application of the principle of mutual recognition to judgments and in criminal matters imposing custodial sentences or measures involving deprivation of liberty for the purpose of their enforcement in the European Union", 2008.
} 
prisoners. ${ }^{16}$ The European Parliament has, in fact, been issuing warnings about poor conditions in prisons in the European Union for some years, notably in $1996^{17}$ and $1999 .{ }^{18}$ The European Council has also sought to strengthen mutual trust in the area of detention and to support the implementation of the Council of Europe's European Prison Rules, which contain protections for human rights in prisons. ${ }^{19}$ The link between prison conditions and the operation of mutual trust was further made clear by the European Parliament's resolution of 27 February 2014, where it expressed concern that the unacceptable conditions in detention facilities within the Union could impact upon the effectiveness and functioning of Union mutual recognition instruments. ${ }^{20}$

Now, the ECJ has directly held that poor prison conditions can act to justify the non-enforcement of an EAW. The Court was, however, rather cautious in its approach, declining to extend the principles applicable to the asylum process to the EAW process. ${ }^{21}$ Where the executing judicial authority finds that there is a real risk for that individual of inhuman or degrading treatment, the execution of the warrant must be postponed. It cannot, however, be abandoned. When postponement is the outcome, the executing member state must inform Eurojust of the reasons for the delay. ${ }^{22}$ The Court reiterated that the executing authority may only decide to hold a person in custody when the procedure for execution is being carried out in a significantly diligent manner so that the duration of detention is

\footnotetext{
162013/C 168 E/11, "European Parliament Resolution of 15 December 2011 on detention conditions in the EU (2011/2897(RSP))", 15 December 2011.

${ }^{17}$ OJ C 32, "Information and Notices" 5 February 1996.

${ }^{18}$ OJ C 98, "Information and Notices" 9 April 1999.

${ }^{19}$ OJ C 115, "Information and Notices" 4 April 2010.

20 2013/2109 (INL), "European Parliament resolution of 27 February 2014 with recommendations to the Commission on the review of the European Arrest Warrant."

${ }^{21}$ Joined Cases C-404/15 \& C-659/15 PPU Aranyosi and Căldăraru, Opinion of Advocate General Bot, delivered on 3 March 2016.

${ }^{22}$ Ibid., 99.
} 
not excessive. ${ }^{23}$ The detention may not be indefinite and the executing authority must give due regard to the presumption of innocence. It is open to the executing authority to bring the detention to an end and impose, as a substitute, provisional release measures to prevent the person from absconding. If the existence of the risk cannot be discounted within a 'reasonable" 24 time, then the executing judicial authority must decide whether the surrender process should be ended.

This caution reflects the ambiguous stance of the Court when it comes to those accused of and convicted of crimes. As Mancano notes, on the one hand, the ECJ favours the ideals of the reintegration and rehabilitation of prisoners, alongside the promotion of human rights, but on the other hand, also views accused persons and prisoners as probationary citizens, less deserving of full protection. ${ }^{25}$ While that is so, the decision of the Court in Aranyosi and Căldăraru is highly significant on a number of fronts. ${ }^{26}$ The critical outcome of the case is that poor prison conditions can justify the non-execution of an EAW. The stakes are therefore high for an executing judicial authority faced with such an argument. In making these difficult judgments, the issuing judicial authority will seek proof that the impugned prison conditions do or do not meet the threshold required to postpone or refuse to execute the EAW. The test for making out

\footnotetext{
${ }^{23}$ Ibid., 100.

${ }^{24}$ Ibid., 105.

${ }^{25}$ Mancano, "Punishment and Rights in European Union Citizenship: Persons or Criminals?" (2018) 24 European Law Journal 206-225; Coutts, "Union citizenship as probationary citizenship: Onuekwere" (2015) Common Market Law Review 52(2) 531. Mancano also raises the possibility that prison conditions which fall short of a violation of Article 3 of the European Convention on Human Rights may nonetheless breach Article 5 thereof, which contains the right to liberty, Mancano, "The right to liberty in European Union law and mutual recognition in criminal matters" (2016) 18 Cambridge Yearbook of European Legal Studies 215; Mancano, "The place for prisoners in EU law?" (2016) 22 European Public Law 717.

${ }^{26}$ Korenica and Doli, "No more unconditional 'mutual trust' between the Member States: an analysis of the landmark decision of the ECJ in Aranyosi and Căldăraru” (2016) 5 European Human Rights Law Review 542.
} 
such a claim, and the evidence to be deployed in such an assessment, are therefore of central importance.

\section{The test for non-execution of a European Arrest Warrant: what constitutes evidence of poor prison conditions?}

The ECJ in Aranyosi and Căldăraru addressed the decisionmaking process which a judicial authority must follow when faced with the question of whether prison conditions justify the postponement or non-execution of an EAW. The first step is for the executing judicial authority to assess the presence of such a risk. In order to conduct that examination, the executing judicial authority must first rely on information that is 'objective, reliable, specific and properly updated on the detention conditions' prevailing in the Member State. ${ }^{27}$ Such a review is directed to the general level of detention conditions in the state. If the judicial authority considers that there is a real risk of inhuman or degrading treatment because of the general conditions of detention in the issuing Member State, a further step in the analytical process must commence - the first step, alone, cannot lead to a decision to refuse to execute a European Arrest Warrant. The judicial authority must go from the general to the particular, and engage in 'a further assessment, specific and precise, of whether there are substantial grounds to believe that the individual concerned will be exposed to that risk' in the requesting Member State. ${ }^{28}$

The two-step nature of the test preferred by the Court is affirmed again in the Court's conclusion, when it states: 'where there is objective, reliable, specific and properly updated evidence' of

\footnotetext{
${ }^{27}$ Ibid.

${ }^{28}$ Ibid.
} 
deficiencies concerning detention conditions which may be systemic or generalised, or which may affect certain groups of people or certain places of detention, the executing judicial authority must then go on to determine 'specifically and precisely' whether there are substantial grounds to believe that the person will be exposed to a real risk of inhuman or degrading treatment. ${ }^{29}$

The decision, and the two-step test, have been followed in the Irish High Court decision of Minister for Justice and Equality $v$. Celmer $(\text { No.1 })^{30}$ and in the subsequent preliminary reference decision of Minister for Justice and Equality v LM (hereafter LM), ${ }^{31}$ which concerned the risk of not receiving a fair trial following changes to the Polish judicial system. ${ }^{32}$ In $L M$, the ECJ again emphasised the importance of mutual trust between Member States in the AFSJ, but found that EAWs could be refused on the basis of a threat to fundamental rights.

The ECJ's preferred test raises questions of what precisely will be considered useful and acceptable sources of evidence to satisfy one or both limbs of the test. It is to these sources, and the possible role of prison inspection and monitoring bodies, that this article now turns.

\subsection{Objective, reliable and properly updated evidence: the first limb of the test}

The ECJ has stated that, when faced with the question of whether prison conditions breach fundamental rights, an executing

\footnotetext{
${ }^{29} \mathrm{Ibid}, 102$.

${ }^{30}$ Minister for Justice and Equality v Celmer (No.1) [2018] IEHC 119

31 Case C-216/18 PPU, Minister for Justice and Equality $v$ LM, ECLI:EU:C:2018:586,

${ }^{32}$ The reasoning in the decision was extended to cover a risk of a particularly serious breach of the right to a fair trial which amounts to a flagrant denial of justice.
} 
judicial authority must first look to the general situation in the Member State's prisons. This examination is directed to the question of whether there is a 'real risk of inhuman or degrading treatment' arising out of the general prison conditions in the Member State. ${ }^{33}$ The Court referred specifically to the European Convention on Human Rights' requirement that prisoners are detained in conditions which guarantee respect for human dignity, and where detention is enforced in a way which does not cause the person distress or hardship of an intensity exceeding the unavoidable level of suffering inherent in detention. The health and well-being of the prisoner must be adequately protected, having regard to the practical requirements of imprisonment. ${ }^{34}$

The ECJ has given specific examples of the kinds of sources of information which the authority should use in its analysis of whether the general conditions of detention comply with fundamental rights. These include, but are not limited to, international court decisions, including European Court of Human Rights' decisions, domestic court decisions, and reports and documents produced by bodies of the Council of Europe or the United Nations. While we now have some indication of the types of evidence which the ECJ will consider acceptable indicators of prison conditions, it still remains the case that, as Van Ballegooij and Bárd argue, 'the Court of Justice will need to specify what is to be accepted by a national court as evidence in surrender proceedings and what not' ${ }^{35}$ What other sources of information might be useful for an executing judicial authority?

\footnotetext{
${ }^{33}$ Joined Cases C-404/15 \& C-659/15 PPU Aranyosi and Căldăraru, para 91.

34 Ibid., para 90, citing ECtHR, Torreggiani and Others v. Italy, Nos $43517 / 09,46882 / 09,55400 / 09,57875 / 09,61535 / 09,35315 / 10$, and $37818 / 10$, judgment of 8 January 2013, para 65 .

${ }^{35}$ Ibid., at p. 461.
} 
Though not mentioned by the ECJ specifically, reports of the European Committee for the Prevention of Torture and Inhuman or Degrading Treatment or Punishment (hereafter "CPT"), a Council of Europe body, are obvious potential sources of information for an executing judicial authority on the prison conditions in a Member State. The CPT undertakes visits to prisons, police stations and psychiatric hospitals in Council of Europe Member States and reports on those visits. It has carried out hundreds of such visits since its first in $1990 .{ }^{36}$ The CPT's originating Convention ${ }^{37}$ gives it the power of unrestricted access to all places of detention and confidential communications between the CPT and prisoners, prison staff and others to whom the CPT wishes to speak. ${ }^{38}$ State parties are required to provide access to their territory and the right to travel without restriction, along with providing full information on places where people are deprived of their liberty are being held. ${ }^{39}$ The CPT undertakes periodic visits to its members once every four years or so, and can make more frequent, ad hoc visits, should there be matters of particular concern it wishes to address. It is for the country visited to decide if the CPT's report will be made public, but its reports invariably are published. It is open to the CPT to make a public statement if the state fails or refuses to cooperate with it. ${ }^{40}$ The CPT is a well-established and highly regarded body, evidenced by the fact that the European Court of Human Rights refers to its reports and standards on a regular

\footnotetext{
${ }^{36}$ See further, the seminal study by Evans and Morgan, Preventing Torture: a study of the European Convention for the Prevention of Torture and Inhuman or Degrading Treatment or Punishment (1998); and Morgan and Evans, (Eds) Protecting prisoners: the standards of the European Committee for the Prevention of Torture in context (1999).

37 "European Convention for the Prevention of Torture and Inhuman or Degrading Treatment or Punishment", ERS 126, 26 November 1987.

${ }^{38}$ It can also be seen in "Explanatory Report to the European Convention for the Prevention of Torture and Inhuman or Degrading Treatment or Punishment", ETS 126, 26 November 1987, para 63.

39 "European Convention for the Prevention of Torture and Inhuman or Degrading Treatment or Punishment", ERS 126, 26 November 1987, Article $8(2)$.

${ }^{40}$ Ibid., Article 10(2).
} 
basis in assessing prisons in Council of Europe Member States. Indeed, the Bremen court which made the preliminary reference leading to the Aranyosi and Căldăraru decision relied on reports of the CPT in its decision. Courts in other cases have also referred to CPT reports in assessing whether prison conditions are deficient. ${ }^{41}$

Other sources also suggest themselves. Another international monitoring body for prisons also exists at the UN level. OPCAT established the Subcommittee on Prevention of Torture and other Cruel, Inhuman or Degrading Treatment or Punishment (hereafter "SPT"), with the power to visit places of detention within states party to the Convention. The SPT seeks to visit each State Party every ten years. Its reports could also be important sources of information for executing judicial authorities.

There are additional possible sources of evidence which could also be helpful for an executing judicial authority. Indicators of a prison such as those included in the Council of Europe's SPACE publications would be of interest. ${ }^{42}$ Those indicators include, for example, the percentage occupancy in the state, and the numbers of deaths of people in custody per year High levels of prison overcrowding, or deaths of prisoners, could be considered as important factors in any assessment of the prison conditions prevalent in a Member State. All of these sources can

\footnotetext{
${ }^{41}$ For examples from Ireland, see: Minister for Justice, Equality and Law Reform v. Rettinger [2010] 3 IR 783; Minister for Justice and Equality v. Tache [2019] IEHC 68; The Minister for Justice and Equality v. Holden [2013] IEHC 62. For examples from the United Kingdom, see: Duarte v. Portugal [2018] EWHC 2995; [2018] 11 WLUK 109; Jane v. Lithuania [2018] EWHC 2691 (Admin); [2018] 10 WLUK 262; Shumba v. France [2018] EWHC 1762 (Admin). In the latter case, the court also referred to the domestic NPM, the Inspector General.

${ }^{42}$ PC-CP (2017)10, “Annual Penal Statistics: SPACE 1 - Prison Populations Survey 2016", Aebi et al, Council of Europe, Survey 2016.
} 
provide evidence of the 'general conditions of detention' in the issuing Member State. ${ }^{43}$

While reports of international monitoring bodies, decisions of the European Court of Human Rights, and statistical information produced on prisons will be useful sources of evidence of prison conditions, they will, on their own, not be sufficient to justify the non-execution of an EAW. Analysis of the constraints on these bodies indicates that the ECJ is right to hold that this kind of information cannot be relied upon, on its own, to draw conclusions about the specific situation to which the person who is the subject of the EAW will be returned to. For example, while the CPT plays a critical role in the promotion of human rights in prisons and its reports hold great weight, inevitably, it can only visit a certain number of prisons in a state during each visit, and can only visit a country so often. Taking Romania, a country which was the subject of the Bremen court's decision as an example, since 2006 the CPT has conducted periodic visits in 2006, 2010, 2014 and 2018, and an ad hoc visit in $2009 .{ }^{44}$ In the same time period, the CPT has conducted periodic visits to Hungary in 2009 and 2013, and ad hoc visits in 2007, 2015 and 2017. This is a frequent visiting pattern for the CPT. By way of contrast, in the same time period, the CPT has conducted three periodic visits to Sweden and no ad hoc visits, ${ }^{45}$ and two periodic visits and no ad hoc visits to mainland Denmark. ${ }^{46}$ When it comes to the scope of a visit, to give an example from Hungary, the 2015 and 2017 ad hoc visits focused on the situation of the detention of foreigners, with the 2017 visit not attending any prisons (transit zones at borders were visited) ${ }^{47}$ and in the 2015

\footnotetext{
43 Joined Cases C-404/15 \& C-659/15 PPU Aranyosi and Căldăraru, paragraph 91 .

${ }^{44}<$ https://www.coe.int/no/web/cpt/romania $>$ (last visited 11 January 2019)

${ }^{45}<$ https://www.coe.int/no/web/cpt/sweden> (last visited 11 January 2019)

${ }^{46}<\mathrm{https}: / / \mathrm{www} . c 0 e . i n t / \mathrm{no} / \mathrm{web} / \mathrm{cpt} / \mathrm{denmark}>$ (last visited 11 January 2019)

$47<\mathrm{https} / / / \mathrm{rm} . c o e . i n t / 16808 \mathrm{~d} 6 f 12>$ (last visited 11 January 2019)
} 
visit, one prison was visited. ${ }^{48}$ In its 2014 periodic visit of Hungary, the CPT visited four prisons and a section of one other. The country overall has 29 prisons. ${ }^{49}$ The SPT visits less frequently, given its worldwide remit. Its most recent visit to Romania was in 2016, where it was highly critical of overcrowding and poor conditions of detention. ${ }^{50}$ It visited Hungary for the first time in $2017 . .^{51}$

A deeper problem also arises in this regard. The CPT is not a judicial body, and is not designed to sit in judgement over Member States' prison systems. As Bicknell and Evans say of the work of the CPT and SPT: 'rather than being primarily concerned with compliance, or accountability for breaches of human rights obligations, they are focused on measures that might be taken in order to ensure that ill-treatment does not occur'. ${ }^{52}$ The question then arises, when a body's efforts are focused on preventing human rights violations, engaging in dialogue with the authorities and encouraging the implementation of recommendations, what effects might there be from using its reports to justify the non-execution of a European Arrest Warrant? Here we have the situation of gathering information for one purpose, but it being potentially used for another. The consequences of this for the relationship between the prison authorities and the CPT merit consideration, as it may be that the possibility of receiving a negative report which could affect the operation of the EAW system could lead

\footnotetext{
$48<$ https://rm.coe.int/16806b5d22> (last visited 11 January 2019)

49 http://www.prisonstudies.org/country/hungary (last visited 11 January 2019)

50

$<\underline{\text { https://www.ohchr.org/EN/NewsEvents/Pages/DisplayNews.aspx?NewsID }}$ $=19953 \&$ LangID $=\mathrm{E}>$ (last visited 11 January 2019)

$51<$ https://www.ohchr.org/EN/HRBodies/OPCAT/Pages/Outline.aspx $>$ (last visited 11 January 2019)

52 Bicknell and Evans, 'Monitoring Prisons: The Increasingly Complex Relationship between International and Domestic Frameworks,' in Daems and Visschers (eds), Europe in Prisons (2017).
} 
to prison authorities being more concerned about CPT visits, and/or more responsive to them. If the latter course were to transpire, this would likely to be positive. States already know that the European Court of Human Rights examine the reports of the CPT in deciding on whether a country is in breach of the Convention, but this may seem a more remote possibility than the prevention of the surrender of European Arrest Warrants. The effects of the complex relationship between States and the CPT of such a development need further consideration and review as the outworkings of this decision come to light.

Another issue concerns the fact that there is no automatic publication of CPT reports or government responses. The decision on publication is a matter for the relevant Council of Europe Member State. ${ }^{53}$ Some states, notably Norway, have agreed to the automatic publication of the report. It is very unlikely that a European Union Member State would refuse to publish a CPT report, and, if it did, it is likely that an executing judicial authority would have even greater concerns about the prison conditions in that Member State.

The acute problem of delay arises when we look at decisions of the European Court of Human Rights. That Court is clearly a highly authoritative source of information about prisons and their compliance, or otherwise, with European safeguards for fundamental rights. Indeed, its findings that the conditions in prisons in Hungary and Romania to breach Article $3,{ }^{54}$ gave rise to the concern in the Aranyosi and Căldăraru decision that the EAWs at issue should not be executed. ${ }^{55}$ Notably, however, these cases highlight the length of time prisoners in both 34001/13, 44055/13 and 64586/13, judgment of 10 March 2015; ECtHR, Iavoc Stanciu v. Romania, Appl. No. 35972/05, judgment of 24 July 2012.

${ }^{55}$ Ibid. 
countries had been complaining about prison conditions, without remedy. In the Hungarian case, the prisoners in the case complained about conditions of detention going back as far as 2006. In the Romanian case, the complaints went back even further than 2006. While pilot decisions given by the European Court of Human Rights (as in the case of Hungary) do concern the current situation in a country's prison system, the Court is often otherwise considering violations that have been ongoing for several years.

As the ECJ itself recognises in Aranyosi and Căldăraru, courts and other bodies providing information on the conditions of detention in a country will always struggle to provide absolutely up-to-date information about specific prisons. Further, not all prisons will be addressed in reports or decisions; only a selection of prisons or parts of prisons in a state are visited by the CPT, for example. As such, while reports of international monitoring bodies such as the CPT or SPT, and decisions of the European Court of Human Rights may highlight that an examination of prison conditions in a state to which a person is to be sent is necessary, a more nuanced and specific evaluation of what those precise conditions are like is required.

\section{2 'Specifically and precisely': what evidence will satisfy the second limb of the test?}

The second stage of the test requires an assessment of prison conditions which must be specific and precise, and directed to the question of whether there are substantial grounds to believe that the particular individual will be exposed to a real risk of inhuman and degrading treatment. The ECJ's reference to specific groups of prisoners implies that, for example, even if there are concerns about the treatment of foreigners, or people with disabilities in prison, evidence of this at only the general 
level will not be enough for non-execution. Its reference to certain places of detention could relate to particular regions, or to particular types of detention institutions e.g. those for pre-trial detention, or for women. In $M L$ the ECJ reiterated that the mere existence of evidence that there are deficiencies is not enough, and that an analysis of the precise situation the person it is actually intended that the person be detained in is necessary. ${ }^{56} \mathrm{In}$ that case, it was accepted by the court that two particular prisons in Hungary should be examined, not all possible places of detention in the country. Clearly, the particular circumstances of the place of detention to which the person is likely to be sent are all-important. ${ }^{57}$ To determine these, the ECJ held that the executing judicial authority must request 'all necessary supplementary information' ${ }^{58}$ from the issuing State on the conditions which that State envisages the person will be detained. That request may also relate to the presence of national or international mechanisms for monitoring prisons in that State. The provision of this information may be subject to a time limit, and the issuing judicial authority may seek assistance from the central authority of the Member State.

In Minister for Justice and Equality v LM, the ECJ held that the executing judicial authority must examine information provided by the individual concerned, as well as 'objective material' from the issuing judicial authority. ${ }^{59}$ What might be acceptable in the prison context?

In answering this question, an analogy can be drawn with how the European Court of Human Rights has managed decisions on

\footnotetext{
${ }^{56}$ Case C-220/19 PPU, $M L$, para 87.

${ }^{57}$ Davidson, Lloyd and Payter, "Extradition law - recent developments and the potential impact of Brexit" (2016) 10 Criminal Law Review 743.

58 Joined Cases C-404/15 \& C-659/15 PPU Aranyosi and Căldăraru, paragraph 94.

${ }_{59}$ Case C-216/18 PPU, Minister for Justice and Equality v LM, para 75, 76, 77.
} 
whether or not extradition to another country gives rise to a risk of a breach of Article 2 or 3 of the Convention. The Court has tended to focus on materials such as diplomatic notes from the country requesting the extradition, particularly declarations prepared specifically for the proceedings and letters from the US Department of Justice. ${ }^{60}$ Such material tends to contain evidence from management staff, and also psychologists and chaplains attached to the prisons which are giving rise to concerns. ${ }^{61}$ Reports of country experts have also been used. ${ }^{62}$ Applicants have, however, also contested the quality and objectivity of evidence provided by the government. ${ }^{63}$

When it comes to the EAW procedure, it is likely that the issuing State will be obliged to identify one or several prisons to which the person is likely to be sent. While the information on what those prisons will come from the issuing judicial authority, the obvious first port of call for information about those prisons will be the relevant prison authorities. Information which comes directly from the prison authorities via the judicial authority has a clear value to the executing authority, but the person who is the subject of the EAW is likely to take issue with its provenance. ${ }^{64}$ Information which is simply descriptive of the nature of prison conditions will likely not be of sufficient depth to meet these requirements. The human rights focus of the ECJ decision suggests that there must be a searching inquiry into the actual state of human rights compliance in a prison, which should

\footnotetext{
${ }^{60}$ ECtHR, Babar Ahmad and Others v. The United Kingdom, Appln. Nos. 24027/07, 11949/08 36742/08, judgment of 10 April 2012.

${ }^{61}$ Ibid.

${ }^{62}$ ECtHR, Harkins and Edwards v. The United Kingdom Appln. Nos. 9146/07, 32650/07, judgment of 17 January 2012.

${ }^{63}$ ECtHR, Trabelsi v. Belgium, Appln No. 140/10, judgment of 16 February 2015.

${ }^{64}$ In a recent Irish case, The Minister for Justice and Equality v. R.O (No. 5) [2018] IEHC 612, the applicant relied extensively on reports of the NPM for prisons in Northern Ireland. The Court took account of this, and conducted a close assessment of the official material provided by the Northern Ireland Prison Service.
} 
require reliance on bodies independent of the authorities themselves.

It is submitted, then, that the executing judicial authority will be likely to require information which comes from a source which is independent of the prison authorities. Reports from independent prison experts, such as psychologists or experts in prison administration, are also likely to be sought. Another mechanisms might be to establish special prison monitors for this task, and one could imagine the development of a bespoke procedure, designed to respond to the particular requirements of the EAW mechanism.

Another possible source of such information also arises, however, and one which, it is submitted, is a more obvious and sensible choice in order to provide relevant information to the executing judicial authority. The ECJ in its decision signals to executing judicial authorities that they may also seek information on any 'national or international procedures and mechanisms for monitoring prison conditions, linked, for example, to visits to prison, which make it possible to assess the current state of detention conditions in those prisons' ${ }^{65}$ The ECJ therefore, is indicating that bodies with a remit to visit and report on prisons will be an important source of information for decision-makers. In the next section, the nature of domestic prison inspection and monitoring bodies will be discussed.

\section{Prison Inspection and Monitoring Bodies as suitable sources of evidence}

\footnotetext{
65 Joined Cases C-404/15 \& C-659/15 PPU Aranyosi and Căldăraru, paragraph 96.
} 
Prison inspection and monitoring bodies are now a wellestablished requirement of international human rights law. Regular inspection and monitoring of prisons is recognised as a necessary safeguard against torture, ill-treatment and other breaches of rights. ${ }^{66}$ Several regional and global human rights instruments advocate for the establishment of inspection and monitoring bodies for prisons. For example, the United Nations' Standard Minimum Rules for the Treatment of Prisoners (SMRs), originally adopted in 1955 and revised in 2015, strongly endorse robust inspection and monitoring bodies for prisons, stating that the purpose of such bodies shall be 'to ensure that prisons are managed in accordance with existing laws, regulations, policies and procedures, with a view to bringing about the objectives of penal and correctional services, and that the rights of prisoners are protected' ${ }^{67}$ Rule 9 of the European Prison Rules ${ }^{68}$ further states the basic principle that 'all prisons shall be subject to regular governmental inspection and independent monitoring'. The commentary to the rules also emphasises the importance of such oversight, noting:

Independent monitoring of prisons, complemented by governmental inspection, are crucial mechanisms to ensure that the provisions of these rules are respected. The objective of both inspection and monitoring is to ensure that prisons are managed in accordance with national law, with a view to bringing about the objectives

\footnotetext{
${ }^{66}$ European Committee for the Prevention of Torture and Inhuman or Degrading Treatment or Punishment, $2^{\text {nd }}$ General Report of the CPT (1992); Carrabine, Criminology: A Sociological Introduction (2004); J. Simon, "The Second Coming of Dignity," in Dolovich and A. Natapoff (Eds), Mapping the New Criminal Justice Thinking, (NYU Press, 2017) 275; Liebling and Crewe, "Prisons Beyond the New Penology: The Shifting Moral Foundations of Prison Management" in Simon and Sparks (Eds), The SAGE Handbook of Punishment and Society (Sage, 2013) 283;

$67 \mathrm{~A} / \mathrm{RES} / 70 / 175$, "Resolution adopted by the General Assembly on 17 December 2015" Rule 83(2).

68 "Recommendation Rec(2006)2 of the Committee of Ministers to Member States on the European Prison Rules", Council of Europe: Committee of Ministers, 11 January 2006, Rule 9.
} 
of penal and corrections services, and to protect the rights of prisoners. ${ }^{69}$

Perhaps the high point for the recognition of the need for prison oversight bodies in international law came in the form of OPCAT. This established a system of regular visits to prisons by expert bodies, known as National Preventive Mechanisms (NPMs), which are independent bodies with the mandate to visit places where people are deprived of their liberty. ${ }^{70}$ The combination of the requirements of OPCAT, the Standard Minimum Rules on the Treatment of Prisoners and the European Prison Rules means that there is now a global consensus that prison inspection and monitoring bodies play a key role in protecting human rights in prisons.

The European Union does not yet have a specific instrument on prison inspection and monitoring, however, the European Parliament has stated a strong view that Member States should implement 'effective and independent national supervision mechanisms for prison and detention centres' ${ }^{71}$ The Parliament has also called on Member States and accession countries to sign and ratify OPCAT and encouraged the EU to make a call to sign and ratify OPCAT part of its policy vis-à-vis third countries. It also advocated for the EU and Member States to collaborate fully with and support these bodies, including by means of appropriate resources and funds. In its 2011 Green Paper, the

\footnotetext{
${ }^{69}$ European Committee on Crime Problems, Council for Penological Cooperation, "Revised commentary to Recommendation CM/Rec(2006)2 of the Committee of Ministers to member States on the European Prison Rules", PC-CP (2018) 1 rev 2, 22 May 2018, commentary to rule 9.

${ }^{70}$ Murray, The Optional Protocol to the UN Convention Against Torture (OUP, 2011); Nowak and McArthur, The United Nations Convention Against Torture (OUP, 2008); Steinerte, "The Jewel in the Crown and Its Three Guardians: Independence of National Preventive Mechanisms under the Optional Protocol to the UN Torture Convention" (2014) 14(1) Human Rights Law Review 1.

${ }^{71}$ 2013/C 168 E/11, "European Parliament Resolution of 15 December 2011 on detention conditions in the EU (2011/2897(RSP))" paragraph 19.
} 
European Council posed a question to the Commission as to how the monitoring of detention conditions by Member States be better promoted, noting its funding of a network of exchange amongst NPMs in Europe. ${ }^{72}$ The European Council further posed a question to the Commission as to how the monitoring of detention conditions by Member States could be better promoted. ${ }^{73}$

While the establishment of prison inspection and monitoring bodies is a requirement for all Member States through their accession to the United Nations Standard Minimum Rules for the Treatment of Prisoners and the Council of Europe's European Prison Rules, there is no single model for such bodies in Europe. No particular type of prison inspection and monitoring body is specifically required and Member States have adopted different types of bodies to fulfil this purpose. For example, in Germany, the National Agency for the Prevention of Torture fulfils the role of NPM, writing reports on the status of torture prevention in places of detention, ${ }^{74}$ while in Belgium, the French General Detention Ombudsman and the Dutch General Detention Ombudsman preform a similar function. ${ }^{75}$ In Finland, the Parliamentary Ombudsman oversees public bodies generally, but also has a remit in visiting prisons and reporting on the conditions in them. ${ }^{76}$ In Ireland, an Office of the Inspector of Prisons publishes reports on prisons visited and general matters of concern such as the complaints procedures available

\footnotetext{
${ }^{72} \operatorname{COM}(2011) 327$ "Strengthening mutual trust in the European Judicial area - A Green Paper on the application of EU criminal justice legislation in the field of detention." European Commission, 14 June 2011, 11 referring to the Peer-to-Peer II Project which funds the European NPM project.

73 Ibid.

$74<$ https://www.nationale-stelle.de/en/home.html $>$ (last visited 11 January 2019)

$75<$ http://www.cglpl.fr/en/> and <https://www.inspectie-jenv.nl/> (last visited 11 January 2019)

$76<$ https://www.oikeusasiamies.fi/en> (last visited 11 January 2019)
} 
in prisons ${ }^{77}$ while in England and Wales, a well-established Inspectorate using qualitative and quantitative methods examines the situation in prisons and reports publicly on its findings. ${ }^{78}$

Independent prison inspection and monitoring bodies, with their focus on human rights compliance, and usually more regular visiting patterns than international prison monitoring bodies, are, it is submitted, very suitable sources of information when an executing judicial authority has concerns about prison conditions in a Member State. They also have strong advantages over information coming from the prison authorities themselves. As Korenica and Doli have argued, 'the executing national court is under the obligation to control the credibility of information received by the issuing Member State court. It should not take for granted every piece of information delivered by the issuing Member State'. ${ }^{79}$ A judicial authority concerned with the protection of fundamental rights which are potentially in jeopardy because of prison conditions must surely take more comfort from the position of an independent body in its assessment of those conditions, than that which is supplied by the prison authorities themselves. Indeed, the ECJ's specific reference to 'objective and reliable' information suggests that information from independent and well-resourced bodies will be preferred. Where a person is contending that $\mathrm{s} / \mathrm{h}$ e will be sent to a place where conditions imperil fundamental rights, it is to the reports of bodies tasked with examining human rights compliance that they are also likely to turn. Indeed, we already see an example of the High Court of England and Wales

\footnotetext{
$77<\mathrm{http}$ ://www.inspectorofprisons.gov.ie/> (last visited 11 January 2019)

$78<\mathrm{https}$ ://www.justiceinspectorates.gov.uk/hmiprisons/national-preventivemechanism/> (last visited 11 January 2019)

${ }^{79}$ Korenica and Doli, "No more unconditional 'mutual trust' between the Member States: an analysis of the landmark decision of the ECJ in Aranyosi and Căldăraru” (2016) 5 European Human Rights Law Review 542, 551.
} 
referring to a report of the Inspector General, which acts as the NPM for France, when concerns were raised in an EAW case concerning prison conditions there. ${ }^{80}$ The practical implications of this development will now be examined.

\section{A New Role for Inspection and Monitoring of Prisons: Becoming an Element of Mutual Trust}

Should domestic prison inspection and monitoring bodies be called upon more frequently to provide evidence in EAW cases, and given the variety of them across the European Union, the next question likely to arise is whether there are certain core features which those bodies should possess to pass the 'objective and reliable' test in specific cases. The first question to arise is whether the domestic body has sufficient powers to get a clear and objective picture of what is happening in prisons. International human rights law contains guidance on the kinds of powers inspection and monitoring bodies should hold. Under rule 84 of the Mandela Rules, inspectors and monitors must have the power to access all information on the numbers of prisoners and places of detention, and on the treatment of prisoners, as well as to choose freely which prisons to visit and to hold private and fully confidential interviews with prisoners and staff. Under Article 20 of OPCAT, NPMs must be granted, at a minimum, similar access and powers. The Council of Europe's European Prison Rules include a statement that the reports of independent monitors shall be made public $;^{81}$ the commentary to the rules goes further, and states that monitoring bodies should have wide authority to access information, choose freely which prisons to

\footnotetext{
${ }^{80}$ Shumba v. France [2018] EWHC 1762 (Admin); [2018] 7 WLUK 261.

81 "Recommendation Rec(2006)2 of the Committee of Ministers to Member States on the European Prison Rules", Council of Europe: Committee of Ministers, 11 January 2006, Rule 93.1.
} 
visit, conduct private and fully confidential interviews with prisoners and prison staff, and make recommendations on what needs to be done to meet standards set by national and international law. ${ }^{82}$ The CPT has also stated regularly that inspectors and monitors should be able to meet with prisoners and receive correspondence from them confidentially. ${ }^{83}$ Frequent announced and unannounced visits is the required CPT standard. ${ }^{84}$ Inspectors and monitors must be able to enter all areas of a prison and walk around freely. ${ }^{85}$ Preventing reprisals and the use of sanctions against people who speak to or provide information to inspectors and monitors is a preoccupation for the CPT and is also explicitly stated in OPCAT. ${ }^{86}$

\footnotetext{
82 European Committee on Crime Problems, Council for Penological Cooperation, "Revised commentary to Recommendation CM/Rec(2006)2 of the Committee of Ministers to member States on the European Prison Rules", PC-CP (2018) 1 rev 2, 22 May 2018, 66.

${ }^{83}$ European Committee for the Prevention of Torture and Inhuman or Degrading Treatment or Punishment, $25^{\text {th }}$ General Report on the CPT's activities (2015); see also, for example, European Committee for the Prevention of Torture and Inhuman or Degrading Treatment or Punishment, Report to the Government of 'The Former Yugoslav Republic of Macedonia' on the visit to 'the former Yugoslav Republic of Macedonia' carried out by the European Committee for the Prevention of Torture and Inhuman or Degrading Treatment or Punishment (CPT) from 6 to 9 December 2016, CPT/Inf (2017) 30; European Committee for the Prevention of Torture and Inhuman or Degrading Treatment or Punishment, Report to the Bulgarian Government on the visit to Bulgaria carried out by the European Committee for the Prevention of Torture and Inhuman or Degrading Treatment or Punishment (CPT) from 25 September to 6 October 2017 (2018).

${ }^{84}$ See, for example: European Committee for the Prevention of Torture and Inhuman or Degrading Treatment or Punishment, Report to the United Nations Interim Administration Mission in Kosovo (UNMIK) on the visit to Kosovo carried out by the European Committee for the Prevention of Torture and Inhuman or Degrading Treatment or Punishment (CPT) from 15 to 22 April 2015, CPT/Inf (2016) 23; European Committee for the Prevention of Torture and Inhuman or Degrading Treatment or Punishment, Report to the Bulgarian Government on the visit to Bulgaria carried out by the European Committee for the Prevention of Torture and Inhuman or Degrading Treatment or Punishment (CPT) from 25 September to 6 October 2017 CPT/Inf (2018) 15.

${ }^{85}$ European Committee for the Prevention of Torture and Inhuman or Degrading Treatment or Punishment, Report to the Government of Cyprus on the visit to Cyprus carried out by the European Committee for the Prevention of Torture and Inhuman or Degrading Treatment or Punishment (CPT) from 23 September to 1 October 2013, supra n 48.

86 UN General Assembly, United Nations Optional Protocol to the Convention against Torture, 9 January 2003, Article 21.
} 
How are domestic judicial authorities or the ECJ likely to deal with such matters? One can imagine an argument over whether the inspection and monitoring body providing information is, for example, sufficiently independent, or whether it has the powers necessary to get a true picture of prison conditions. It is notable that all the countries which came in for special mention as having problematic prison conditions by the Advocate General in the Aranyosi and Căldăraru Opinion have ratified OPCAT and established NPMs. However, the CPT has expressed concern, for example, that supervisory judges in Slovenia were not visiting prisons sufficiently regularly and were usually accompanied by prison staff. ${ }^{87}$ The CPT has also stated its disquiet about the level of resources afforded to domestic inspection and monitoring bodies on several occasions. ${ }^{88}$ A national judicial authority may well be faced with the questions of the quality of the information provided by a body which is poorly resourced, or its impartiality.

As a result, we may, in the longer term, see a requirement for minimum standards in how inspection and monitoring of prisons across the European Union operate, and, at the least, in how information is provided to executing courts. While the ECJ has

\footnotetext{
87 European Committee for the Prevention of Torture and Inhuman or Degrading Treatment or Punishment, Report to the Slovenian Government on the visit to Slovenia carried out by the European Committee for the Prevention of Torture and Inhuman or Degrading Treatment or Punishment (CPT) from 2 March to 4 April 2017, CPT/Inf (2017) 27.

${ }^{88}$ For example, European Committee for the Prevention of Torture and Inhuman or Degrading Treatment or Punishment, Report to the Government of Ireland on the visit to Ireland carried out by the European Committee for the Prevention of Torture and Inhuman or Degrading Treatment or Punishment (CPT) from 16 to 26 September 2014, CPT/Inf (2015) 38; European Committee for the Prevention of Torture and Inhuman or Degrading Treatment or Punishment, Report to the Bulgarian Government on the visit to Bulgaria carried out by the European Committee for the Prevention of Torture and Inhuman or Degrading Treatment or Punishment (CPT) from 24 March to 3 April 2014, CPT/Inf (2015) 12; European Committee for the Prevention of Torture and Inhuman or Degrading Treatment or Punishment, Report to the Lithuanian Government on the visit to Lithuania carried out by the European Committee for the Prevention of Torture and Inhuman or Degrading Treatment or Punishment (CPT) from 27 November to 4 December 2012, CPT/Inf (2014) 18.
} 
made it clear that Member States may not apply the perhaps higher standards of their own legal system to that of another Member State, mutual trust in inspection and monitoring may require an EU-wide benchmark for the powers, methods, standards and reporting style of these bodies. A useful template in this regard would be the Mandela Rules' statement of the basic powers which inspection and monitoring bodies should have, such as free access to all prisons, and powers to speak in confidence to prisoners and staff.

Another intriguing possibility emerges from the decision. As noted above, the ECJ has indicated that judicial authorities may request the issuing member state to describe the existence of any national or international procedures and mechanisms for monitoring detention conditions. ${ }^{89}$ The thrust of the decision by the Court concerning domestic inspection and monitoring bodies concerns the Court's interest in them as information-giving bodies. However, by requiring information on the existence of those bodies, the Court is indirectly indicating that the presence of those bodies is itself a matter to take into account when deciding if there is a real risk of a breach of the person's fundamental rights. An Irish case has followed this lead. ${ }^{90}$ There, an argument was raised about poor prison conditions in a particular prison in Northern Ireland. The High Court of Ireland, in making an order for surrender, noted that there was a 'robust inspectorate systems' for prisons, and that the prison authorities had a track record of responding to those reports. Donnelly J held that 'on its own that would not be decisive, but it is a factor that I can take into account'. ${ }^{91}$

\footnotetext{
${ }^{89}$ Joined Cases C-404/15 \& C-659/15 PPU Aranyosi and Căldăraru, 96.

${ }^{90}$ The Minister for Justice and Equality v. R.O. (No. 5) [2017] IEHC 612.

${ }^{91}$ Ibid., para 23.
} 
As such, domestic inspection and monitoring bodies, and the responsiveness of the authorities to them, are viewed as measures of comfort against the possibility of detention conditions which are in breach of fundamental rights, and as aspects of the guarantee against torture and inhuman or degrading treatment. If it transpires that judicial authorities end up, in practice, regularly factoring in the presence of monitoring bodies into their assessment of protections of fundamental rights, then we see the European Union position on inspection and monitoring as being ahead of that under the European Convention on Human Rights. While the Council of Europe has stated that there must be inspection and monitoring bodies in the European Prison Rules, the European Court of Human Rights has yet to examine the question of whether their presence or absence is a factor to be considered when examining whether a person's rights under Article 3 have been violated. Should the ECJ extend its analysis in Aranyosi and Căldăraru in this way, it will have gone significantly further than the European Court of Human Rights in this area and far beyond viewing inspection and monitoring bodies as merely useful sources of information.

Another related consequence of the decision concerns prison conditions themselves. Given the significance of the threat they pose to mutual trust, we are also likely to see increasing pressure from the European Union on Member States to improve their prison conditions generally. The Opinion of the Advocate General in Aranyosi and Căldăraru contains robust statements on the need to improve prison conditions within EU Member States and points to increasing activity on the part of EU institutions in this field. The Opinion reproaches Member States for their desultory performance in the protection of rights in prisons, referring to a 'damaging failure' to act on the part of 
Member States and Union institutions to act ${ }^{92}$ These strong rebukes are likely to result in more efforts by the EU to encourage, or force, Member States to improve their prisons. A very strong concern is that these efforts may result only in improvements to conditions in which people returned via the EAW procedure are housed. While such an outcome would obviate concerns on the part of Member States about the nonreturn of prisoners, it would clearly lead to a highly unsatisfactory situation from the point of view of equal treatment. More positively, it is likely that we will also see increasing EU attention on mechanisms set up to ensure human rights are protected in prisons, such as inspection and monitoring bodies.

\section{Conclusion: a needed role for prison inspection and monitoring to support mutual trust}

The decision in Aranyosi and Căldăraru has rightly garnered a great deal of attention for its efforts to balance fundamental rights and the operation of the EAW system, for its assessment of mutual trust and for its examination of Convention rights. ${ }^{93}$ The outworkings of the decision in these fields will shape them for many years to come. ${ }^{94}$ The challenge of untangling and understanding the connections between the concepts of freedom,

\footnotetext{
92 Joined Cases C-404/15 \& C-659/15 PPU Aranyosi and Căldăraru, 176.

${ }^{93}$ Anagnostaras, "Mutual confidence is not blind trust! Fundamental rights protection and the execution of the European arrest warrant: Aranyosi and Căldăraru" (2016) 53 Common Market Law Review 1675; Ouwerkerk, "Balancing Mutual Trust and Fundamental Rights Protection in the Context of the European Arrest Warrant: What Role for the Gravity of the Underlying Offence in ECJ Case Law?" (2018) 26(2) European Journal of Crime, Criminal Law and Criminal Justice 103.

${ }^{94}$ For analysis and critique of the concept of 'balance' in this area, see Guild, Carrera and Balzacq, 'The Changing Dynamics of Security in an Enlarged European Union' in Bigo, Carrera, Guild and Walker (Eds.)) Delivering Liberty, Europe's $21^{s t}$ Century Challenge. London: Ashgate (2011), pp. 3148.
} 
security and justice remains. ${ }^{95}$ How might we find ways to give practical expression to the protection of fundamental rights which enhances mutual trust? In seeking ways to ensure that fundamental rights are properly reconciled with the principle of mutual trust, scholars have made useful proposals including the need for the ECJ to stress the importance of representation by defence lawyers and legal aid. ${ }^{96}$ The effects of the Court's decision for inspection and monitoring bodies, and their potential role in providing such protection of fundamental rights, has been, comparatively speaking, overlooked in these assessments. As this analysis shows, however, the judgment puts those bodies firmly in the spotlight, placing them at the heart of decisions concerning mutual trust and the smooth working of the EAW procedure. Prison inspection and monitoring bodies are needed to provide information about the human rights standards applicable and enforced in particular prisons to individual executing authorities, but also more generally, to allow Member States and their citizens to have a clearer picture of what is happening in the prisons of the European Union.

It is submitted that this need has become even more pressing in light of the $M L$ decision. That case made it even clearer than Aranyosi and Căldăraru that the precise conditions in which a surrendered person will be held are all-important in cases where there is a dispute as to whether the fundamental rights of a surrendered person will be imperilled by reason of prison conditions. As the ECJ held in $M L$, 'solely the actual and precise conditions of detention in the prisons in which ... it is likely that the person will be detained, including on a temporary or transitional basis ${ }^{97}$ should be examined by the executing judicial authority. As such, very granulated, specific and up-to-

\footnotetext{
${ }^{95}$ Van Ballegooij and Bárd, op cit (n 4).

${ }^{96} \mathrm{Ibid}$.

${ }^{97}$ Para 117.
} 
date reports will be of critical importance in EAW decisionmaking. This suggests an important role for bodies which can provide such information, including prison inspection and monitoring bodies. Minimum standards for their operation are likely to be a very significant consequence of the decision in the longer term, which will accelerate pre-existing efforts by the EU to encourage Member States to improve their oversight of prisons. Without these efforts and developments, there is a risk that the consequences of the case will give rise to another example ${ }^{98}$ of mutual recognition having gone too far without an accompanying set of equivalent standards and standards and practices, in this scenario concerning both the inspection and monitoring of prisons and the management of prisons themselves. It is also submitted that giving more attention to inspection and monitoring bodies, and supporting them to share experiences across Member States, could also respond to Sicurella's call for the creation of a shared vision of criminal justice and a culture of trust within the European Union. ${ }^{99}$

The $M L$ decision also, however, gives rise to some potentially troubling scenarios. In $M L$ the ECJ indicated that it would be satisfied with assurances from the authorities in the requesting state concerning prison conditions, and that executing judicial authorities should rely on that assurance, at least in the absence of specific reasons to believe that fundamental rights will be endangered. In the specific circumstances of the case, the authorities involved were the Hungarian Ministry of Justice. It is notable that in the ECJ's decision in $M L$ no reference was made to the use of independent forms of information concerning prison

\footnotetext{
98 See further: Peers, 'Mutual recognition and criminal law in the European Union: Has the Council got it wrong? (2004) 41 Common Market Law Review 5; Mitsilegas, 'The Limits of Mutual Trust on Europe's Freedom, Security and Justice' 31 Yearbook of European Law 319

${ }^{99}$ Sicurella, 'Fostering a European criminal law culture: In trust we trust' (2018) 9(3) New Journal of European Criminal Law 308.
} 
conditions. While the ECJ makes clear that there must be an overall analysis of all the information available on prison conditions, which could include that produced by prison oversight bodies, the primary source will continue to be state authorities. It is submitted that the ECJ and executing judicial authorities should not be afraid to conduct a more searching inquiry than that suggested in $M L$, and be sure to seek the views of human-rights protecting prison oversight bodies when examining prison conditions. In this analysis, prison inspection and monitoring bodies should themselves be viewed as ways of enhancing mutual trust because of their emphasis on human rights protections. Prison inspection and monitoring bodies already play a key role under international human rights law concerning the prevention of ill-treatment and the promotion of rights within prison. The decision in Aranyosi and Căldăraru and its subsequent application in domestic courts and before the ECJ means that, they now also have a potentially central position in the maintenance of the Area of Freedom, Security and Justice. This position should be used as a way of ensuring that fundamental rights are adequately protected in the administration of the EAW procedure. 